総説

\title{
水溶液反応場におけるセラミック薄膜プロセッシング
}

\author{
鵜沼 英郎，松嶋 雄太 \\ 山形大学大学院理工学研究科, ₹ 992-8510 米沢市城南 4-3-16.
}

\section{Ceramic Thin Film Processing in Aqueous Solutions}

\author{
Hidero Unuma and Yuta Matsushima \\ Graduate School of Science and Engineering, Yamagata University, 4-3-16 Jonan, Yonezawa 992-8510, Japan.
}

Received January 18, 2012

\section{SYNOPSIS}

This article reviews the techniques of the deposition of ceramic thin films from aqueous solutions and the development of the water-based starting solution for the dip-coating deposition of ceramic thin films. As a solidprecipitation reaction proceeds at an appropriate rate in an aqueous solution in contact with a substrate, heterogeneous nucleation takes place followed by crystal growth to form a ceramic thin film. The precipitation reaction is designed depending on the kind of the metal ion comprised in the ceramic film. In the present article, the following advantages unique to the aqueous solution-based thin film deposition are outlined. It is easy to scale-up the film deposition process, and the film thickness is homogeneous throughout the film. The nano-scale microstructure can be imprinted by using surfactant templates which should extend the application of the films. Calcium phosphate thin films deposited with the mediation of an enzyme were found to promote bone formation by in vivo tests. A homogeneous precursor solution of barium titanate was prepared. The solution may be advantageous over conventional alkoxidebased solutions or sol suspensions in terms of long-term stability and precise composition control.

KEY WORDS

thin film, aqueous solution, precipitation, precursor solution, enzyme

\section{1 緒 言}

水溶液中で進行する多種多様な無機化学反応を利用して, セラミックスの生成と形態制御を同時になおかつ温和な条件 下で行いうることは, 水溶液プロセスに特有の大きな利点で ある.また，よく知られているようにバイオミネラリゼー ションは自然界における優れた水溶液プロセスのシステムで あり，この過程の中に含まれる固体生成・形態制御の要素を 人工材料の合成過程に取り入れようとする試みが世界中で行 われている.

水溶液中での固体生成の反応速度を制御することによって 固体の不均一核形成が優勢になるような条件を作り，その核 を成長させることによって基材の上にセラミック薄膜を形成 する手法が, 1980年頃から研究され始めた. ちょうど無電解 メッキで金属薄膜ができるように, 水溶液に浸した基材上に セラミック薄膜が形成されるこの方法は, 実用上の観点から も魅力に富むものであるため,すでに広範な物質に適用され，
包括的な総説も書かれている ${ }^{1-3)}$. セラミック薄膜を作製する ための他の方法,すなわち気相法やゾルゲル法と比較すると， 水溶液プロセスによるセラミック薄膜の形成は, 真空や高価 な装置を必要としないこと, 高温での熱処理を必要としない こと, 複雑形状の基板にも均一な厚さの製膜が可能なこと, スケールアップが容易なこと,メソスケールでの微細構造制 御が可能なことなどの長所を有する. その反面, 薄膜が水を 多く含んだり結晶性が低くなったりする場合があること, 製 膜速度が低いこと, 膜物質によって化学反応を選択しなくて はならないこと, 複酸化物の製膜が比較的難しいこと，など の短所もある.ここに挙げた短所は簡単に解決できるもので はないので, 現在工業的に採用されているセラミック薄膜の 製膜プロセスが，すぐに水溶液プロセスに転換しうるという ものではない，しかし，気相法やゾルゲル法では作り得ない ような機能や構造を持つような薄膜を作ることができるなら ば,そこに水溶液プロセスの存在価値が見出せることになる. 
また, 環境負荷の低隇や作業環境の安全確保という観点か らも，セラミックス製造プロセスの「脱・有機溶媒」化への 取り組みがなされている中, 水溶液プロセスを実用に耐えう るものにしていく努力が継続されなくてはならない.

本稿では, 水溶液プロセスで作られる薄膜と水溶液系原料 の開発について, 著者らの研究例を中心に, 特に応用への展 開を意図した観点から概説する.

\section{2 水溶液中での薄膜形成反応と薄膜の種類}

液相から固相が生成するときには,まず核形成が起こり次 いでその核が成長していく，このとき, 生成する固相と親和 性のある固体(基材)がすでに液相内に存在し, なおかつ固相 の過飽和度が高すぎない場合には, 基材上に優先的に核形成 が起こる(不均一核形成)。このようにしてできた核が成長す れば，基材上に固相が薄膜状に形成される.

DeGuire ${ }^{1.3)}$ は水溶液からのセラミック薄膜の作製方法を 4 種類に分類している. すなわち, Chemical bath deposition (CBD, pH や温度を調節して, 薄膜析出に最適な速度で固体 を析出させる方法), Liquid phase deposition (LPD, 水溶性の 金属フロリド錯体を加水分解して金属酸化物を析出させる方 法), SILAR (基材を, 金属塩の水溶液と沈殿剤の水溶液に交 互に繰り返し浸漬する方法), Electroless deposition (ED, 触媒 で付活した基材表面に, 金属イオンの酸化還元反応を利用し て固体を析出させる方法) である. 一方, 固体析出反応の種 類に基づいた分類も可能であり, その方が膜物質の性質と化 学反応との相関を理解しやすいように思われる.したがって, 本稿では, 酸化還元反応, 塩の加水分解, 錯体の配位子置換 反応の 3 種類の化学反応に基づいて既存の手法を分類してみ る.

第一の, 酸化還元反応を利用する製膜方法は, 比較的初期 に確立された．鉄が $\mathrm{Fe}^{2+}$ と $\mathrm{Fe}^{3+}$ の状態をとるように，水溶液 中で金属イオンが 2 種類以上の酸化数をとる場合, 一般には 高酸化数のイオンの(水)酸化物の方が低い溶解度をもつ. 東 工大の阿部らが開発した, $\mathrm{Fe}^{2+}$ イオンの酸化によるマグネタ イトの製膜技術 (フェライトメッキ法 $)^{4}$ は, 酸化還元反応を 用いた代表的な製膜法である。酸化還元反応を用いれば, $\mathrm{SnO}_{2}, \mathrm{MnO}_{2}, \mathrm{CeO}_{2}, \mathrm{Co}_{3} \mathrm{O}_{4}, \mathrm{NiO}$ などの製膜 ${ }^{5-11)}$ も可能であり, たとえば $\mathrm{SnO}_{2}$ 薄膜は $\mathrm{SnCl}_{2} \cdot 2 \mathrm{H}_{2} \mathrm{O}$ と $\mathrm{KNO}_{3}$ の水溶液から次の 化学反応にしたがって形成される.

$$
\begin{aligned}
& \mathrm{Sn}^{2+}+\mathrm{NO}_{3}{ }^{-}+2 \mathrm{H}^{+} \rightarrow \mathrm{Sn}^{4+}+\mathrm{NO}_{2}{ }^{-}+\mathrm{H}_{2} \mathrm{O} \\
& \mathrm{Sn}^{4+}+2 \mathrm{H}_{2} \mathrm{O} \rightarrow \mathrm{SnO}_{2}+4 \mathrm{H}^{+}
\end{aligned}
$$

このうち，(2)の反応は速く進むので, $\mathrm{SnO}_{2}$ を薄膜状に得よ うとすれば(1)の見かけの反応速度(単位時間当たりの反応量) を制御すればよいことになる。具体的には, 出発溶液の溶質 の濃度と反応温度を制御する，ただし，酸化還元反応を適用 できる系は, 金属イオンが複数の酸化状態をとりうるものに 限られるので, 膜物質の種類にも限りがある. また, 金属个 オンの種類が異なれば, 沈殿析出の条件も異なるので, 複酸
化物の薄膜を作ったりドーピングを行ったりすることは, 必 ずしも容易ではない.

酸化還元反応を用いた場合に限らず，一般にセラミック薄 膜は親水性の基材との親和性が高いので, 水溶液プロセスを 用いてガラス, セラミックス, 親水性ポリマ一表面などに製 膜を行うことができる. Fig. 1 に $30 \mathrm{~cm}$ 角のガラス板に作製し た厚さ $70 \mathrm{~nm} の \mathrm{SnO}_{2}$ 薄膜の写真を示す. 薄膜の存在を分かり やすくするために，ガラスの右側 $1 / 4$ あたりに製膜していな い部分を意図的に残している. また，水溶液プロセスで作製 した薄膜には, 膜厚の均一性が高く基材の表面形状への追随 性が良いという特徵もある. Fig.2には, ガラス繊維の織布に $\mathrm{SnO}_{2}$ 薄膜を (a) 水溶液プロセスと (b)市販ゾル溶液のディップ コーティング法で作製した例を示す.ゾルのディップコー ティングでは, ゾル溶液の表面張力によって溶液がたまる部 分ができるために, 結果的に膜厚が不均一になることがある が, 水溶液プロセスでの製膜においてはそのようなことが起 こりにくい.

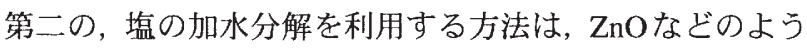
に水酸化物の状態を長時間経ることなく酸化物が析出する系 に適用される。特に, $\mathrm{ZnO}$ は出発溶液, 析出条件, 添加物の 有無によって, 粒子の形態や薄膜の微細構造を広い範囲で制 御することができるため, 膨大な研究の蓄積がある ${ }^{12)}$. たと えば, 水和 $\mathrm{Zn}\left(\mathrm{NO}_{3}\right)_{2}$ などの水溶性塩とHMT (ヘキサメチレン テトラミン)などの沈殿剤前駆体を含む水溶液を加熱すると, HMT がアンモニアに変化するにつれて水溶液の $\mathrm{pH}$ が上昇 し, $\mathrm{Zn}\left(\mathrm{NO}_{3}\right)_{2}$ が加水分解されて $\mathrm{ZnO}$ が粒子状または薄膜状に 生成する ${ }^{13)}$. 固体の析出反応自体は塩の加水分解であるが, 目的の反応速度を制御するためには多くの工夫の余地がある. 伊崎ら ${ }^{14-16)}$ は, $\mathrm{Zn}\left(\mathrm{NO}_{3}\right)_{2}, \mathrm{Fe}\left(\mathrm{NO}_{3}\right)_{3}, \mathrm{Ce}\left(\mathrm{NO}_{3}\right)_{3}$ などの硝酸塩水 溶液に DMAB (ジメチルアミンボラン) を加え, DMABによ る $\mathrm{NO}_{3}{ }^{-} \rightarrow \mathrm{NO}_{2}{ }^{-}$の還元と, それに伴う $\mathrm{pH}$ の上昇を利用して原 料塩を加水分解し, $\mathrm{ZnO}, \mathrm{Fe}_{3} \mathrm{O}_{4}, \mathrm{CeO}_{2}$ などの薄膜を作製して いる.

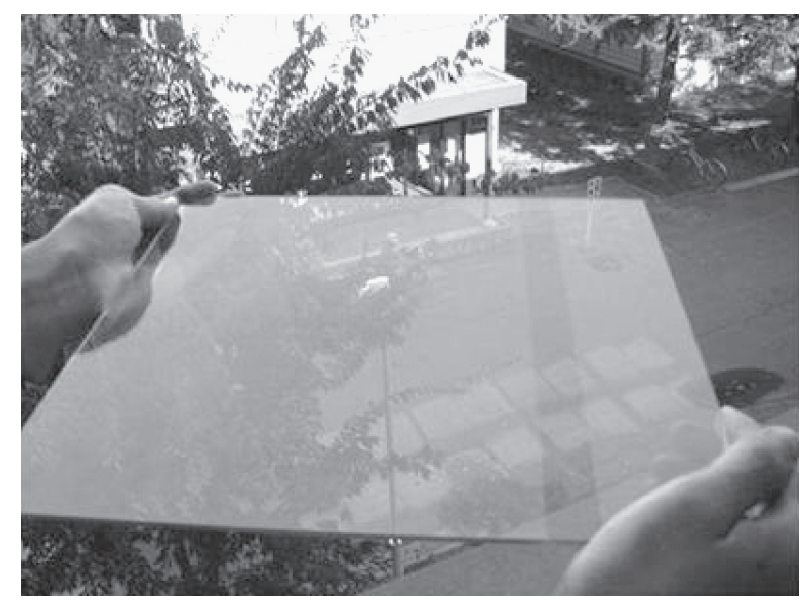

Fig. 1 Appearance of a $70 \mathrm{~nm}$-thick $\mathrm{SnO}_{2}$ coating on a pane of glass.A streak of area in the right half was not coated on purpose to show the contrast with the coating. 

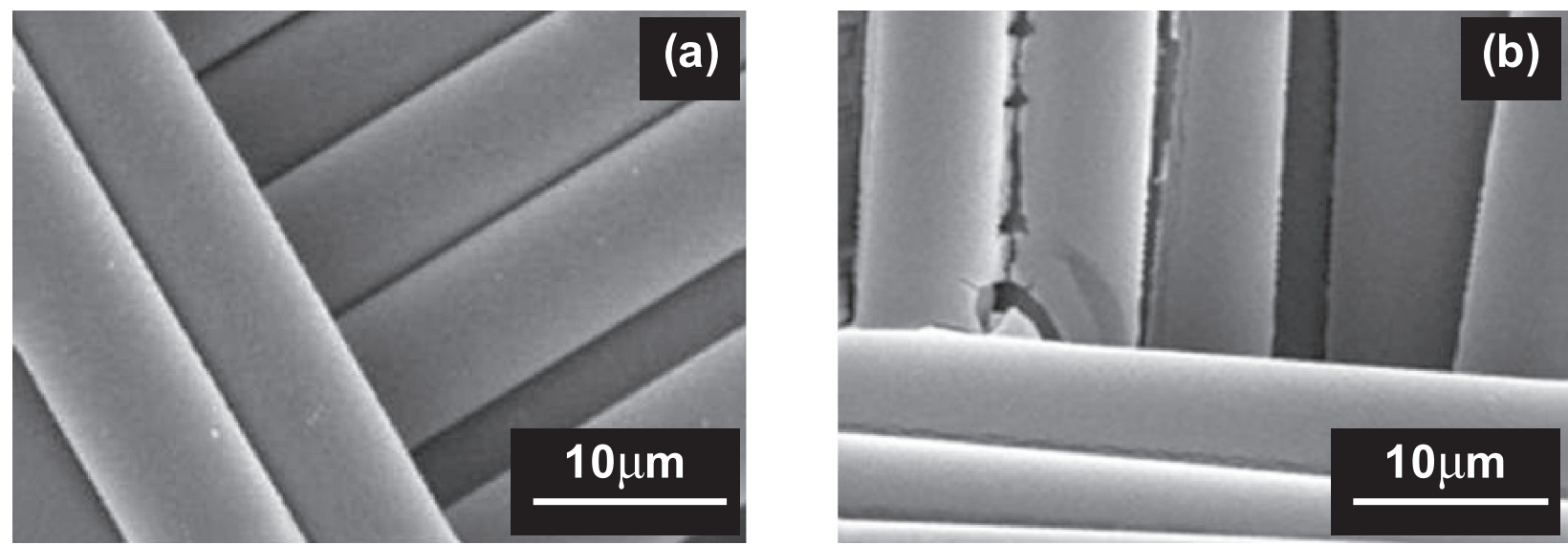

Fig.2 SEM images of glass fiber cloth coated with $\mathrm{SnO}_{2}$ by (a) an aqueous solution process and (b) the dip-coating of a sol.

ただし, 水酸化物の状態を長時間経ることなく酸化物が析 出する系はそれほど多くなく,特に金属イオンの価数が+2や +3の場合には水酸化物が最安定相であることが多い. そのた め, 例えば $\mathrm{In}_{2} \mathrm{O}_{3}$ や CdOなどの薄膜を作ろうとする場合には, 一旦 $\mathrm{In}(\mathrm{OH})_{3} や \mathrm{Cd}(\mathrm{OH})_{2}$ のような水酸化物の薄膜を作製して, それを数百 ${ }^{\circ} \mathrm{C}$ の温度で焼成する必要が生じてしまう.

第三の, 錯体の配位子置換反応を利用する方法は, 膜物質 による制約が最も小さく, 潜在的には広範囲な系に適用可能 な方法と考えられる. $\mathrm{Si}^{4+}$ や $\mathrm{Ti}^{4+}$ のように, 正電荷が高くてサ イズの小さな金属イオンは, 硝酸塩などの水溶性の塩を作り にくいが，フッ化物イオンを配位子としたフロリド錯体㓌イ オン, あるいは $\mathrm{O}_{2}{ }^{2-}$ を配位子とするペルオキシド錯体陰イオ ンとして水に溶ける. 乳酸イオンや硫酸イオン, アンモニア なども安定化を助ける配位子となりうる. 金属イオンを安定 化しているこれらの配位子を, アクア $\left(\mathrm{H}_{2} \mathrm{O}\right)$ 配位子またはヒ ドロキシド $\left(\mathrm{OH}^{-}\right)$配位子で置換していけば, 中心金属イオンは やがて酸化物として析出する*1.この方法で, $\mathrm{SiO}_{2}{ }^{17)}, \mathrm{TiO}_{2}{ }^{18-22)}$, $\mathrm{ZrO}_{2}{ }^{23,24)}, \mathrm{WO}_{3}{ }^{25)}$ などの単酸化物薄膜のほか, $\mathrm{SrTiO}_{3}{ }^{26)}$ 薄膜の ような複酸化物薄膜が作製された。また, テトラヒドロキシ ド亜鉛酸イオン $\left(\left[\mathrm{Zn}(\mathrm{OH})_{4}\right]^{2-}\right)$ やチタンのペルオキシド錯体陰 イオン $\left(\left[\mathrm{TiO}\left(\mathrm{O}_{2}\right)_{2}(\mathrm{OH})_{2}\right]^{2-}\right)$ が, 自発的に分解して $\mathrm{ZnO}$ や $\mathrm{TiO}_{2}$

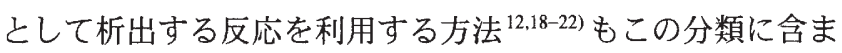
れる.

上記の他，基材の表面に酵素を固定化し，その酵素反応生 成物を沈殿剤として基材表面に固体を薄膜状に堆積させる方 法(酵素支援製膜法)がある ${ }^{27}$. 本稿ではその例についても後 述する。

\section{3 薄膜のナノ構造制御}

水溶液プロセスで形成される薄膜の微細構造制御の方法に は, 基板の親水性/疎水性や酸塩基の硬さ/軟らかさの差を利

\footnotetext{
${ }^{* 1} \mathrm{~F}^{-}, \mathrm{O}_{2}{ }^{2-}, \mathrm{OH}^{-}$配位子に対するフロロ, ペルオキソ, ヒドロキソという呼称は 古い命名法によるものである. 2005 年のIUPAC勧告では, それぞれフロリ ド,ペルオキシド, ヒドロキシドである。
}

用した二次元パターニングや，基板の凹凸に固体析出を追従 させる微細構造制御 ${ }^{28.29)}$ が報告されている. 両親媒性分子や ブロックコポリマーの自己組織化分子集合体をテンプレート としたメソポーラス体の合成はすでに良く知られた方法であ るが, 著者の知る限り, 水溶液プロセスで作られる薄膜をメ ソポーラス化する報告はなされていない. 著者らは, $\mathrm{C}_{16} \mathrm{TAC}$ (セチルトリメトリアンモニウムクロリド, 温度や濃度などの 条件によって, ヘキサゴナル, キュービック, ラメラなどの 自己組織化分子集合体を作ることが知られている ${ }^{30)}$ )の自己組 織体をテンプレートとして, 以下の様な手順に従ってラメラ 状のメソポーラス $\mathrm{MnO}_{2}$ 薄膜を析出させた ${ }^{31}$.

$\mathrm{MnCl}_{2} \cdot 4 \mathrm{H}_{2} \mathrm{O}$ を $0.01 \mathrm{M}, \mathrm{KBrO}_{3}$ または $\mathrm{NaBrO}_{3}$ を $0.1 \mathrm{M}$, $\mathrm{C}_{16} \mathrm{TAC} 0.1 \mathrm{M}$ 含む水溶液を調製し，これにガラス基板を浸 して $333 \mathrm{~K} て ゙ 12 \mathrm{~h}$ 保持した. この出発溶液は, 室温では全く 化学反応を起こさないが, $333 \mathrm{~K}$ では $\mathrm{BrO}_{3}{ }^{-}$による $\mathrm{Mn}^{2+}$ の酸 化とそれに伴う $\mathrm{MnO}_{2}$ の析出(式3)が徐々に進行するので, 基 板上に選択的に $\mathrm{MnO}_{2}$ 薄膜が形成される.

$$
3 \mathrm{Mn}^{2+}+\mathrm{BrO}_{3}^{-}+3 \mathrm{H}_{2} \mathrm{O} \rightarrow 3 \mathrm{MnO}_{2}+\mathrm{Br}^{-}+6 \mathrm{H}^{+}
$$

薄膜の成長時に, $\mathrm{C}_{16} \mathrm{TAC}$ 自己組織化集合体が薄膜内に取り 込まれるので, 製膜後に集合体を洗浄除去すればメソポーラ スな薄膜が得られる.

得られた薄膜の X 線回折図を Fig. 3に示す. 比較のために $\mathrm{C}_{16} \mathrm{TAC}$ を使用せずに作製した薄膜の回折図も併せて示す. $\mathrm{C}_{16} \mathrm{TAC}$ TAンプレートに用いて作製した薄膜では, 低角度側 に周期的な回折線が現れる。これを詳細に解析したところ, 得られた薄膜は, $\mathrm{MnO}_{2}$ ナノシートが約 $3.0 \mathrm{~nm}$ の間隔で積層 されたような, ラメラ状のナノ微細構造をもつものであるこ とがわかった。

$\mathrm{C}_{16} \mathrm{TAC}$ 使わずに析出させた薄膜は $\gamma$ 型の $\mathrm{MnO}_{2}$ であった ことから, 上記のナノシートも $\gamma$ 型の構造に基づいたもので あろうと推測される. ラメラ状の $\gamma-\mathrm{MnO}_{2}$ 薄膜は, レドック スキャパシタの電極活物質として高い性能を示すものと期待 される。 


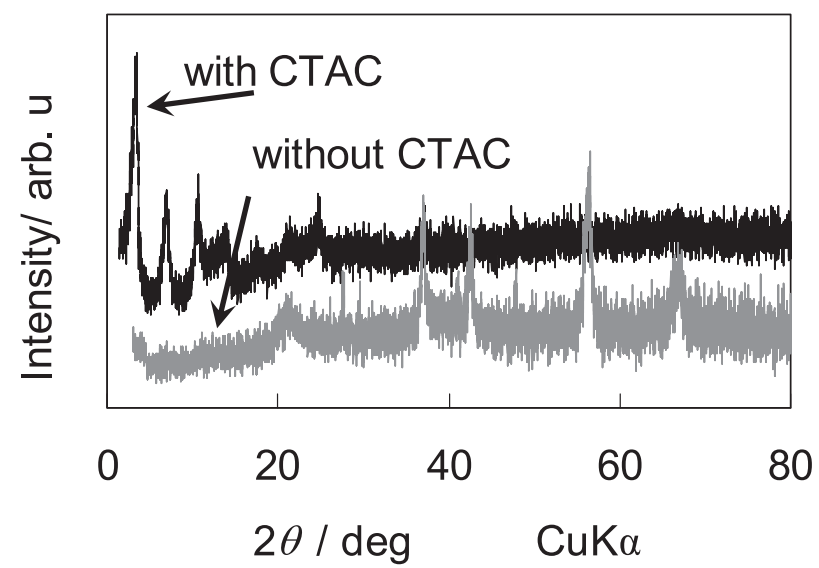

Fig.3 X-ray diffraction profiles of $\mathrm{MnO}_{2}$ thin films deposited with and without $\mathrm{a}_{16} \mathrm{TAC}$ template.

\section{4 醭素支援製膜法とその応用}

酵素反応の中には金属イオンの沈殿剤を生産するものがあ る. たとえば, ウレアーゼは尿素の加水分解(アンモニアと 炭酸の生成) を触媒し, アルカリフォスファターゼはリン酸 エステルの加水分解 (無機リン酸の生成)を触媒する.これら の酵素反応を適当な金属イオンの存在下で行えば, 酵素の近 傍でのみ金属水酸化物, 炭酸塩, リン酸塩が析出する. そこ で, 酵素を基材表面に固定化して同様のことを行えば，基材 表面に目的物を薄膜状に形成することができる.

著者らは, 以下のようにしてゼラチン修飾チタン上にリン 酸カルシウム薄膜を形成した ${ }^{32}$. まず, 純チタンの表面を濃 硝酸で親水化した後に, APTES (アミノプロピルトリエトキ キシラン)のカップリング剤を媒介として表面をゼラチンで 修飾した，つぎに，この表面にウレアーゼを固定化して，硝 酸カルシウム, リン酸二水素アンモニウム, 尿素を含む水溶 液に $310 \mathrm{~K}$ で3時間浸した. この間に, チタン表面近傍での尿 素の加水分解 (式 4) とリン酸カルシウムの析出 (式 5)が進行 し, 低結晶性水酸アパタイトを主成分とするリン酸カルシウ ム薄膜でチタン表面が被覆された。

$$
\begin{aligned}
\mathrm{H}_{2} \mathrm{NCONH}_{2}+3 \mathrm{H}_{2} \mathrm{O} & \rightarrow 2 \mathrm{NH}_{3}+\mathrm{H}_{2} \mathrm{CO}_{3} \\
10 \mathrm{Ca}^{2+}+6 \mathrm{PO}_{4}{ }^{3-}+ & 2 \mathrm{NH}_{3}+2 \mathrm{H}_{2} \mathrm{O} \\
& \rightarrow \mathrm{Ca}_{10}\left(\mathrm{PO}_{4}\right)_{6}(\mathrm{OH})_{2}+2 \mathrm{NH}_{4}{ }^{+}
\end{aligned}
$$

リン酸カルシウム被覆チタンと無処理チタンとを, 骨代謝 能力に乏しい糖尿病ラットの頭蓋骨に埋植し, 4 週間後に実 験部を摘出して脱灰組織切片を観察したところ, Fig.4に示す ように, リン酸カルシウム被覆チタン $(\mathrm{g} / \mathrm{CaP}-\mathrm{Ti})$ を埋植した 場合には，チタンに接触して新生骨の形成が認められた。比 較対象の無処理チタンは繊維性組織で覆われ, 新生骨の形成 は認められなかった。このことから, 酵素支援製膜法で作製 したリン酸カルシウム薄膜は, 新生骨の形成を促進する機能 を有することがわかる.

酵素反応の媒介によって生成する無機固体には,リン酸力

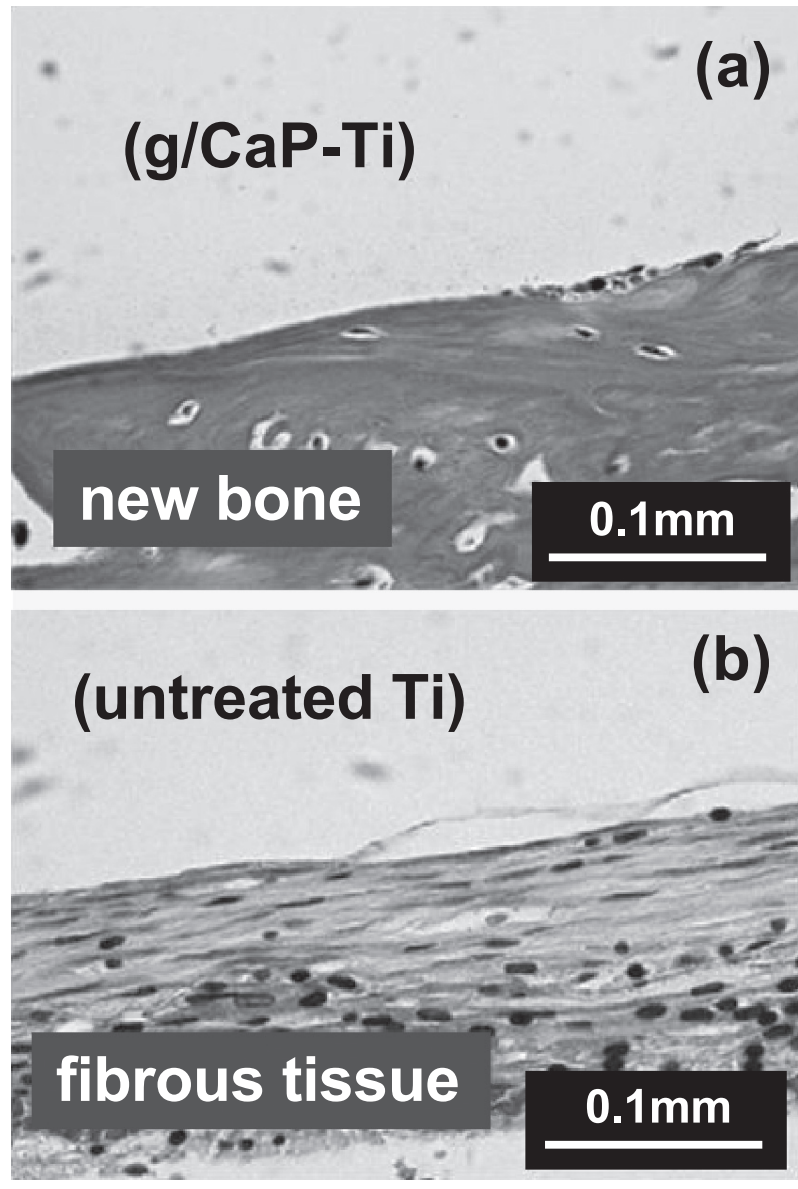

Fig.4 Decalcified Histological micrographs of the areas adjacent to titanium implants (a) with and (b) without a ureasemediated calcium phosphate coating.

ルシウムのほか $\mathrm{CaCO}_{3}, \mathrm{ZnO}, \mathrm{SiO}_{2}, \mathrm{TiO}_{2}$ など多くの種類があ る.また，酵素を基材の上や基材の内部に固定化することに より, 2次元パターニングを施した薄膜, 中空粒子や3次元レ プリカ(これらもテンプレート上への薄膜と見なせる)などを 温和な条件下で作製することが可能である.このように, 酵 素反応を利用することができる点も, 水溶液プロセスの特徵 の一つである.

\section{5 セラミックス前駆体水溶液}

ディップコート法やスピンコート法はセラミック薄膜の作 製法として優れた簡便性を有しており, 導電性 $(\mathrm{GZO})$ 薄膜や 光触媒 $\left(\mathrm{TiO}_{2}\right)$ 薄膜を作製するためのゾル懸濁液が市販された りもしている.しかし, ゾル憅濁液や金属アルコキシド溶液 には, それ自体の安定性が十分ではなかったり, 複酸化物用 の出発溶液の調製が難しいなどの問題が内在する.著者らは, 完全に均一な水溶液のチタン酸バリウム用のコート溶液を開 発することに成功した ${ }^{33-35)}$.

チタン酸バリウムは電子セラミックスの代表的な材料であ り, 現在主にコンデンサ用途に使用されている.チタン酸バリ ウムでは, 特にチタン化合物の化学的反応性の高さがネック 
となり，これまで水溶性の前駆体が開発されてこなかった。 それに対し筆者らは, チタン源にペルオキシドクエン酸チタン 錯体, バリウム源にクエン酸バリウム水溶液を使用すること で, 安定な水溶性のチタン酸バリウム前駆体を得ることに成 功した.この前駆体水溶液は極めて安定で, 年単位の保管の 後も沈殿を生じない.この溶液は, 液体状態のまま使用すれば 薄膜作製用のコーティング夜としての利用することができ33), また, 乾燥させたゲル状固体とすることで, 焼成によりチ夕 ン酸バリウムを与える原料として利用することができる ${ }^{34)}$.

Fig.5は, ディップコート法を用いて水溶性前駆体溶液より 作製した透光性チタン酸バリウム薄膜の光学写真である. 表 面を親水化処理した石英ガラス基板を繰り返し水溶液に浸し て引き上げることで, 基板上に約 $200 \mathrm{~nm}$ の厚さの薄膜を成膜 した. 顕微鏡観察等を用いた詳細な評価によると, 薄膜は200 $\mathrm{nm}$ 以下程度の微細な粒子で構成された多結晶膜であり, 比較 的平滑な表面を有していた。

また, 溶液状態を出発とする本手法で得られるチタン酸バ リウムは, 組成の均一性に優れる.この特徵は, チタン酸バリ ウムにドーパントを添加する際に特に有効に働く. Fig.6に,
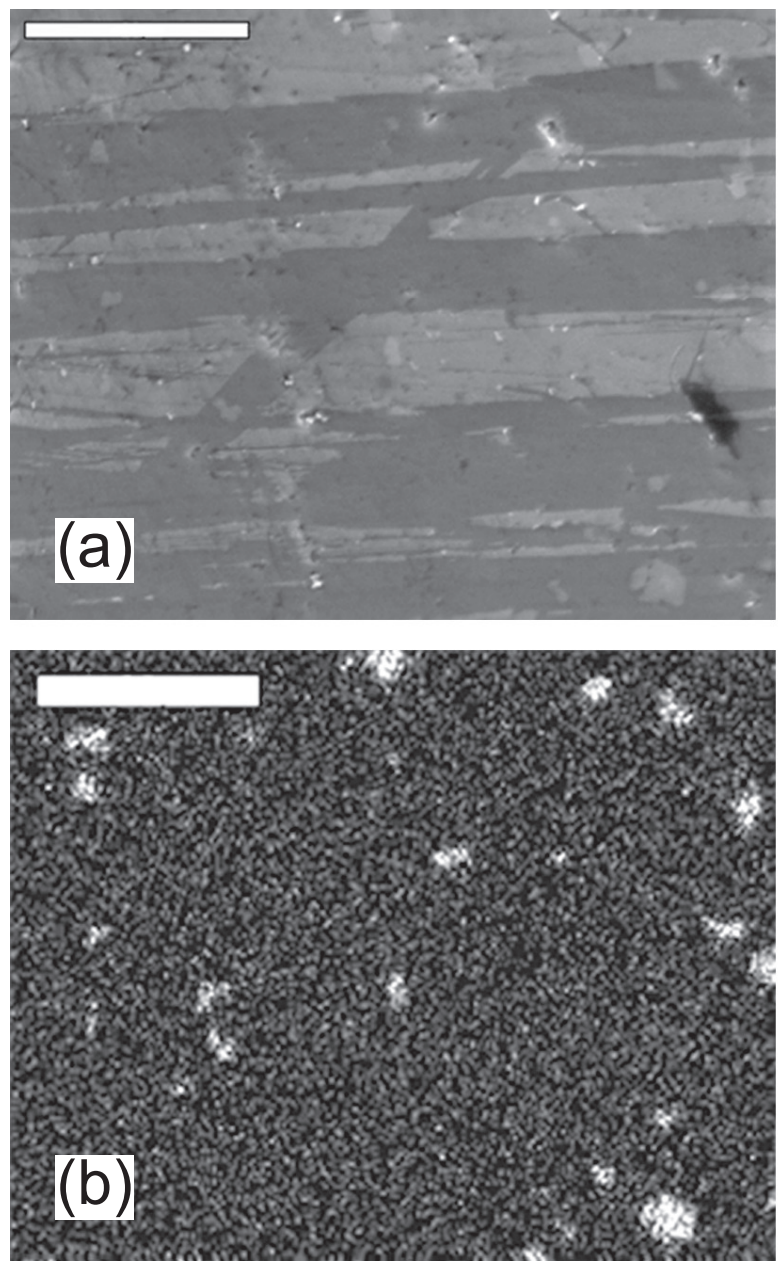

2種類の合成法で作製したHoドープチタン酸バリウムの走査 型電子顕微鏡一エネルギー分散型 X 線分光分析 (SEM-EDS) 分析の比較を示す. Fig.6 (a) および(b) は, 従来の固相反応法

\section{$\mathrm{BaTHO}_{3} \mathrm{BaTHO}_{3} \mathrm{BaTiO}, \mathrm{BaT}$}

\section{$\mathrm{Ba}^{\prime} \mathrm{HiO}_{3} \mathrm{BaTiO}_{3} \mathrm{BaTiO}_{3} \mathrm{BaT}$}

\section{$\mathrm{BaTiO}_{3} \mathrm{BaTiO}_{3} \mathrm{BaTiO}_{8} \mathrm{BaT}$}

\section{$\mathrm{BaTiO}_{3} \mathrm{BaTiO}_{3}$ Balı $10 \mathrm{~mm}$}

Fig.5 Optical image of a transparent $\mathrm{BaTiO}_{3}$ film formed on the quartz substrate by a water-based dip-coating method.
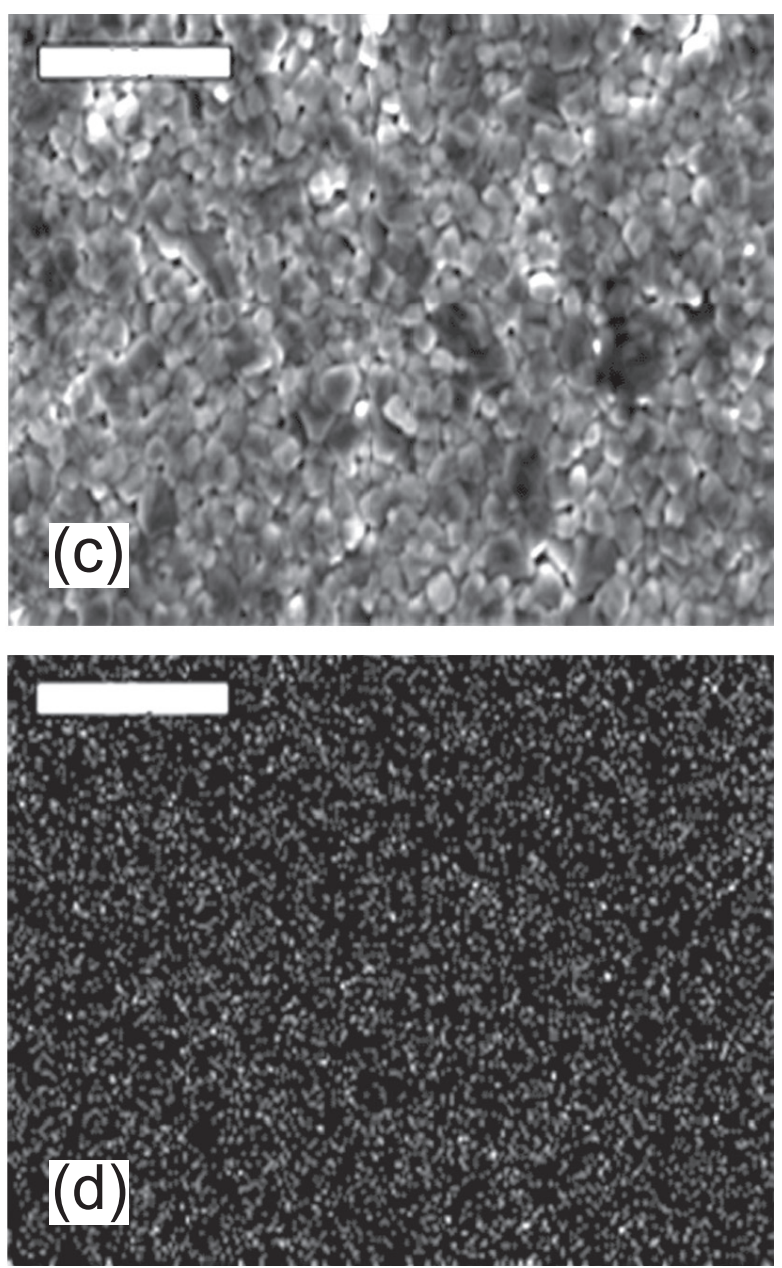

Fig.6 Comparison of structures of sintered body and Ho distribution between the pellets prepared by two methods. (a), (b) solid state reaction (scale bar $=20 \mu \mathrm{m}$ ); (c), (d) water-soluble precursor (scale bar $=10 \mu \mathrm{m}$ ). (a) and (c) show SEM images of the cross-section of the pellets. (b) and (d) are the Ho mapping of the areas shown in (a) and (c), respectively. 
で作製したペレットの状態で, (a)がSEM観察による組織, (b) がその視野における Ho の分布状態を表わしている，固相反 応法で作製したペレットは，一見均一に見えるものでも, Ho の分布に注目するといくつもの凝集部が見られた(Fig.6 (b)中 の白色のドットが固まっている部分). すわなち, 添加したHo の大部分はチタン酸バリウム結晶中に取り込まれていないこ とがわかる.このような不均一な組織では, 混合粉研条件や 焼成条件の微妙な違いがペレット間での特性のばらつきを引 き起こす原因になりうることが予想される. 一方, 水溶液前 駆体を原料に作製した Ho ドープチタン酸バリウムでは, Ho が均一に分布していることがわかった(Fig.6(d)).こちらの方 法で作製した試料では，X線を用いた詳細な構造的評価によ り，ドープされた Hoがチタン酸バリウム結晶構造中に取り 込まれていることが確認された ${ }^{35}$.

特にチタン酸バリウムなどの複合酸化物においては, 水系 プロセスの利点は単に「有機溶媒を使用・排出しない」とい う環境への配慮にとどまらない. チタン源としてしばしば用 いられるチタンイソプロポキシドは加水分解性が高く, 市販 試薬の純度が限定される上, 試薬調製の際の取り扱いに注意 を要する. 一方, チタン酸バリウムでは, Ba/Ti 比のわずかな ずれが電気・焼結特性に大きく影響を与えることが知られて いる ${ }^{36.37)}$. 化学組成を厳密に制御する上で，「意図しない加水 分解による試薬調製段階での組成ずれ」等の問題を容易に回 避することのできる水溶性前駆体は, 高性能チタン酸バリウ ムを合成する上で非常に有効であると言える.

\section{6 ま と め}

水溶液プロセスで作られるセラミック薄膜の種類, 析出方 法, ナノ微細構造制御, 生医学的機能評価の例, およびチ夕 ン酸バリウムの均一水溶液前駆体の開発について概略を記し た. 水溶液反応場では, 本稿に記した以外にも多種多様な化 学反応や物理化学現象が進行しうるが, セラミックプロセッ シングに利用されてきたものは, まだそれらの一部でしかな いようにも思える. その意味で, 気相法や固相法が比較的成 熟度の高い手法であるのに対し, 液相法, 特に水溶液プロセ スは未開発の能力を秘めた手法とも言える.この潜在能力を さらに引き出し, 優れたセラミック製造プロセスの実現に繋 げていくことが望まれる.

\section{文献}

1) T.P. Niesen and M.R. De Guire: "Deposition of Ceramic Thin Films at Low Temperatures from Aqueous Solutions", J. Electrochem., 6(2001) 169-207.

2) Y. Gao and K. Koumoto: "Bioinspired Ceramic Thin Films Processing: Present Status and Future Perspectives", Cryst. Growth Design, 5(2005)1983-2017.

3) H. Parikh and M.R. De Guire: "Recent Progress in the Synthesis of Oxide Films from Liquid Solutions", J. Ceram. Soc. Jpn., 117(2009)228-235.
4) M. Abe and Y. Tamaura: "Ferrite-Plating in Aqueous-Solution -A New Method for Preparing Magnetic Thin-Film", Jpn. J. Appl. Phys., Part 2, 22(1983)L511-L513.

5) H. Unuma, H. Takabatake, K. Watanabe, T. Ogata, and M. Sugawara: "Preparation of $\mathrm{SnO}_{2}$ Thin Films by the OxidativeSoak-Coating Method", J. Mater. Sci. Lett., 21 (2002)12411243.

6) H. Unuma, H. Takabatake, S. Takeda, M. Sakai, K. Watanabe, and M. Sugawara: "Antimony Doping of TinOxide Coatings Prepared by the Oxidative-Soak-Coating Method", J. Mater. Sci. Lett., 22(2003) 1359-1361.

7) H. Unuma, T. Kanehama, K. Yamamoto, K. Watanabe, T. Ogata, and M. Sugawara: "Preparation of Thin Films of $\mathrm{MnO}_{2}$ and $\mathrm{CeO}_{2}$ by a Modified Chemical Bath (OxidativeSoak-Coating) Method", J. Mater. Sci., 38(2003)255-259.

8) H. Unuma, Y. Saito, K. Watanabe, and M. Sugawara: "Preparation of $\mathrm{Co}_{3} \mathrm{O}_{4}$ Thin Films by a Modified Chemical Bath Method", Thin Solid Films, 468(2004)4-7.

9) Y. Saito, K. Kaga, M. Tsutsumida, and H. Unuma: "Preparation of $\mathrm{Fe}_{3} \mathrm{O}_{4}$ Thin Films by a Chemical Bath Method", Chem. Lett., 34(2005)1202-1203.

10) A.J. Varkey and A.F. Fort: "Solution Growth Technique for Deposition of Nickel Oxide Thin Films", Thin Solid Films, 235(1993)47-50.

11) K. Tsukuma, T. Akiyama, and H. Imai: "Hydrolysis Deposition of Thin Films of Antimony-Doped Tin Oxide", J. Amer. Ceram. Soc., 84(2001)869-871.

12) T. Kawano and H. Imai: "Nanoscale Morphological Design of $\mathrm{ZnO}$ Crystals Grown in Aqueous Solutions", J. Ceram. Soc. Jpn., 118(2010)969-976.

13) L. Vayssieres: "Growth of Arrayed Nanorods and Nanowires of $\mathrm{ZnO}$ from Aqueous Solutions", Adv. Mater., 15(2003)464466.

14) M. Izaki and Y. Saijo: "Transparent Conducting and Highly Stable Indium-Incorporated Zinc Oxide Film Prepared by Chemical Reactions", J. Electrochem. Soc., 150(2003)C73C76.

15) M. Izaki and O. Shinoura: "Room-Temperature Deposition of Defect-Free Magnetite Film by Chemical Reaction from an Aqueous Solution", Adv. Mater., 13(2001)142-145.

16) M. Izaki, T. Saito, M. Chigane, M. Ishikawa, J. Katayama, M. Inoue, and M. Yamashita: "Low Temperature Deposition of Cerium Dioxide Film by Chemical Reaction", J. Mater. Chem., 11 (2001)1972-1974.

17) H. Nagayama, H. Honda, and H. Kawahara: "A New Process for Silica Coating", J. Electrochem. Soc., 135(1988)2013-2016.

18) S. Deki, Y. Aoi, O. Hiroi, and A. Kajinami: "Titanium (IV) Oxide Thin Films from Aqueous Solution", Chem. Lett., 1996 (1996)433-434. 
19) Y. Gao, Y. Masuda, Z. Peng, T. Yonezawa, and K. Koumoto: "Room Temperature Deposition of a $\mathrm{TiO}_{2}$ Thin Film from Aqueous Peroxotitanate Solution", J. Mater. Chem., 13(2003) 608-613.

20) S. Yamabi and H. Imai: "Crystal Phase Control for Titanium Dioxide Films by Direct Deposition in Aqueous Solutions", Chem. Mater., 14(2002)609-614.

21) Y.-F. Gao, M. Nagai, W.S. Seo, and K. Koumoto: "Thick Transparent Rutile $\mathrm{TiO}_{2}$ Films Crystallized in Solution", Langmuir, 23(2007)4712-4714.

22) S. Deki, S. Iizuka, A. Horie, M. Mizuhata, and A. Kajinami: "Nanofabrication of Metal Oxide Thin Films and NanoCeramics from Aqueous Solution", J. Mater. Chem., 14(2004) 3127-3132.

23) Y. Gao, Y. Masuda, H. Ohta, and K. Koumoto: "RoomTemperature Preparation of $\mathrm{ZrO}_{2}$ Precursor Thin Film in an Aqueous Peroxozirconium-Complex Solution", Chem. Mater., 16(2004)2615-2622.

24) K. Kuratani, M. Uemura, M. Mizuhata, A. Kajinami, and S. Deki: "Novel Fabrication of High-Quality $\mathrm{ZrO}_{2}$ Ceramic Thin Films from Aqueous Solution", J. Am. Ceram. Soc., 88 (2005) 2923-2927.

25) S.-H. Baeck, T.F. Jaramillo, G.D. Stucky, and E.W. McFarland: "Synthesis of Tungsten Oxide on Copper Surfaces by Electroless Deposition", Chem. Mater., 15(2003)3411-3413.

26) Y. Gao, Y. Masuda, T. Yonezawa, and K. Koumoto: "SiteSelective Deposition and Micropatterning of $\mathrm{SrTiO}_{3}$ Thin Film on Self-Assembled Monolayers by the Liquid Phase Deposition Method", Chem. Mater., 14(2002)5006-5014.

27) H. Unuma, Y. Matsushima, and T. Kawai: "Enzyme-Mediated Synthesis of Ceramic Materials", J. Ceram. Soc. Japan, 119 (2011)623-630.

28) S. Iizuka, S. Ooka. A. Nakata, M. Mizuhata, and S. Deki: "Development of Fabrication Process for Metal Oxide with
Nano-Structure by the Liquid-Phase Infiltration (LPI) Method", Electrochim. Acta, 51 (2005) 802-808.

29) S. Deki, S. Iizuka, A. Horie, M. Mizuhata, and A. Kajinami: "Liquid-Phase Infiltration (LPI) Process for the Fabrication of Highly Nano-Ordered Materials", Chem. Mater., 16(2004) 1747-1750.

30) N.K. Raman, M.T. Anderson, and C.J. Brinker: "TemplateBased Approaches to the Preparation of Amorphous, Nanoporous Silicas", Chem. Mater., 8(1996)1682-1701.

31) Y. Hayasaka, T. Kawai, K. Matsuda, Y. Matsushima, and H. Unuma: "Preparation and Electrochemical Properties of Lamellar-Structured $\mathrm{MnO}_{2}$ Thin Film", Proc. 24th Fall Meeting Ceram. Soc. Jpn., (2011)1B26.

32) T. Furusawa, M. Sato, T. Okudera, K. Monma, Y. Matsushima, and $\mathrm{H}$. Unuma: "In vitro and in vivo evaluation of titanium coated with gelatin and calcium phosphate", Proc. Annual Meeting Ceram. Soc. Jpn., (2012)2L06.

33) K. Iwase, Y. Matsushima, and T. Kawai: "Transparent Thin Films of Barium Titanate Prepared from Aqueous Dip-coat Solution", Proc. Annual Meeting Ceram. Soc. Jpn., (2010) 94.

34) S. Kasuga, K. Iwase, T. Kawai, and Y. Matsushima: "Doping Phenomena of $\mathrm{Ho}$ in $\mathrm{BaTiO}_{3}$ Prepared from a Water Soluble Precursor", Proc. 24th Fall Meeting Ceram. Soc. Jpn., (2011) 352.

35) S. Kasuga, K. Iwase, T. Kawai, and Y. Matsushima: "Investigation of Doping Phenomena of Ho-doped $\mathrm{BaTiO}_{3}$ with a Water-based Sol-gel Method", $12^{\text {th }}$ Conference of the European Ceramic Society, (2011)\#1066.

36) J.-K. Lee, K.-S Hong, and J.-W. Jang: "Roles of Ba/Ti Ratios in the Dielectric Properties of $\mathrm{BaTiO}_{3}$ Ceramics", J. Am. Ceram. Soc., 84(2001)2001-2006.

37) J.S. Choi and H.G. Kim: "Influence of Stoichiometry and Impurity on the Sintering Behaviour of Barium Titanate Ceramics", J. Mater. Sci., 27(1992)1285-1290. 